\title{
Microbiota oral e retal de calitriquídeos (Callithrix sp.) em área antropizada de Mata Atlântica, Rio de Janeiro, Brasil
}

\author{
[Oral and rectal microbiota of callitrichids (Callithrix sp.) in an anthropized area of the \\ Atlantic Forest in Rio de Janeiro, Brazil] \\ D.D.A. Albuquerque ${ }^{1}$,F.B. Figueiredo ${ }^{2}$, M.L. Brandão ${ }^{3}$, M.C. Furtado ${ }^{3}$, \\ J.L.P. Cordeiro ${ }^{3}$, M.C.S. Lourenço ${ }^{4}$, S.F. Bruno ${ }^{1}$ \\ ${ }^{1}$ Aluna de pós-graduação - Universidade Federal Fluminense - Niterói, RJ \\ ${ }^{2}$ Instituto Carlos Chagas- Fiocruz/PR - Curitiba, PR \\ ${ }^{3}$ Fiocruz da Mata Atlântica - Fundação Oswaldo Cruz - Rio de Janeiro, RJ \\ ${ }^{4}$ Instituto Nacional de Infectologia Evandro Chagas - Fundação Oswaldo Cruz - Rio de Janeiro, RJ
}

\begin{abstract}
Proximity of nonhuman primates (NHP) to humans can be considered a risk factor for transmission of pathogens between these two populations. This study investigated the oral and rectal aerobic bacterial microbiota of marmosets in an anthropized area of the Atlantic Forest located in Rio de Janeiro, Brazil, and performed phenotypic tests for detection of multidrug-resistant bacteria. Twenty-one samples (14 from the oral cavity and seven from the rectum) were collected from 14 Callithrix sp. captured in two sites of the forest near human dwellings. The most frequent species identified from the oral cavity swabs were Klebsiella oxytoca (50.0\%), K. pneumoniae (28.6\%), Kluyvera ascorbata (21.4\%) and Stenotrophomonas maltophilia (21.4\%), whereas the species most commonly identified from the rectum swabs were K. pneumoniae (85.7\%), Enterobacter spp. (42.9\%) and Escherichia coli (28.6\%). All isolates of family Enterobacteriaceae showed no extended spectrum $\beta$-lactamase production by disk-diffusion and automated detection tests. In the search for carbapenem-resistant enterobacteriaceae these isolates presented no resistance to the imipenem, meropenem and ertapenem antibiotics. The isolate of Staphylococcus aureus was susceptible to oxacillin and the isolate of Enterococcus was susceptible to vancomycin. All isolated bacteria showed zoonotic potential, thus posing a risk to species conservation and public health.
\end{abstract}

Keywords: marmosets, multidrug-resistant bacteria, rain forest

\section{RESUMO}

A proximidade dos primatas não humanos $(\mathrm{PNH})$ com o ser humano pode ser considerada um fator de risco para transmissão de bactérias entre essas duas populações. Neste estudo, foi investigada a microbiota anfibiôntica aeróbica oral e retal de calitriquídeos em um fragmento de Mata Atlântica localizado no Rio de Janeiro, Brasil, e foram realizados testes fenotípicos para detecção de bactérias multirresistentes nos isolados encontrados. Foram capturados 14 calitriquídeos e coletadas 21 amostras (14 de cavidade oral e sete de cavidade retal) em dois pontos da mata próximos às habitações humanas. As espécies mais frequentes, na cavidade oral, foram Klebsiella oxytoca (50,0\%), K. pneumoniae (28,6\%), Kluyvera ascorbata $(21,4 \%) e$ Stenotrophomonas maltophilia $(21,4 \%)$ e, na cavidade retal, K. pneumoniae $(85,7 \%)$, Escherichia coli $(28,6 \%)$ e Enterobacter spp. (42,9\%). Todos os 48 isolados da família Enterobacteriaceae foram negativos para ESBL (betalactamase de espectro ampliado), mostrando-se não produtores da enzima nos dois métodos utilizados: disco-aproximação e método de detecção automatizado. Na pesquisa de ERC (enterobactérias resistentes a carbapenêmicos), esses mesmos isolados não apresentaram resistência aos antibióticos imipenem, meropenem e ertapenem. Todas as bactérias isoladas apresentam um potencial zoonótico, o que representa um risco à saúde pública e à conservação das espécies.

Palavras-chave: calitriquídeos, bactérias multirresistentes, floresta tropical

Recebido em 6 de maio de 2019

Aceito em 27 de novembro de 2019

E-mail: vetdaniduarte@gmail.com 


\section{INTRODUCTION}

Nonhuman primates (NHP) of genus Callithrix have wide geographic distribution and are considered native to the Brazilian northeastern, central-western and southeastern regions (Rocha and Passamani, 2009). $C$. jacchus and $C$. penicillata, which are native to the Northeast and Central-west regions of Brazil, respectively, as well as their fertile hybrids, are species with high potential for colonization of forest habitats (Begotti and Landesmann, 2008) and great capacity of adaptation to anthropized environments, which enables a closer contact of these NHP with human beings, thus favoring possible transmission of diseases (Daszak et al., 2001; Begotti and Landesmann, 2008). These marmosets, especially their hybrids, are present in forest regions in the interior of Rio de Janeiro state, and are also regularly observed in the streets, parks and squares of the city of Rio de Janeiro (Ruiz-Miranda et al., 2011).

NHP can harbor a number of bacteria, namely, Streptococcus pneumoniae, Bordetella bronchiseptica, Pasteurella multocida, Staphylococcus aureus, Klebsiella pneumoniae, Hemophilus influenzae, Pseudomonas sp., Proteus sp., Corynebacterium sp., Salmonella sp., Shigella sp., Pneumococcus sp., Hemophilus sp., Yersinia sp., Mycobacterium sp., Campylobacter sp., Vibrio sp. and Listeria sp. (Burke et al., 2009; Carvalho et al., 2014; Sales, 2015; Cruz et al., 2017; Shigeno et al., 2018; Takehara et al., 2019). In humans, these bacteria may constitute important opportunistic pathogens that promote severe conditions of urinary tract infection, gastroenteritis, liver abscesses, and septicemia (Carrier et al., 2009; Singh et al., 2016).

The spread of antimicrobial-resistant bacteria (ARB) among domestic and wild animals and humans is a growing hypothesis. It suggests that wildlife can serve as reservoir, vector, and bioindicator of these antibiotic-resistant bacterial pathogens in the environment (Carroll et al., 2014; Vittecoq et al., 2016). Wild animals do not naturally come into contact with antimicrobials; however, they can become infected with ARB of human origin through the increasingly closer living with human beings (Carroll et al., 2014). This threat is especially important with regards to zoonotic bacteria, because a single pathogen can endanger the health of wild and domestic animals and humans (Kim et al., 2017).

In this context, this study aimrd to assess the oral and rectal aerobic bacterial microbiota of marmosets (Callithrix sp.) and conduct phenotypic tests for detection of multidrugresistant bacteria in the population of these animals in an Atlantic Forest fragment in Rio de Janeiro.

\section{MATERIAL AND METHODS}

Samples were collected from the oral cavity and rectum of Callithrix sp., both males and females, regardless of age, at the "Fiocruz Mata Atlântica" Campus (CFMA) (22 $56^{\prime} 22.79^{\prime \prime} \mathrm{S}$; 43 24' 12.80" $\mathrm{W})$ located in the Jacarepaguá neighborhood, city of Rio de Janeiro (RJ), Brazil. The Campus is set in the southeast slope of the "Maciço da Pedra Branca" State Park, which is one of the largest forest remnants in urban area in the world (Reflorestamento..., 2014), located in the west district of the city.

Geographically, the CFMA is composed of three phytophysiognomies: 1) peridomicile region (forest under early successional stage, in mosaic with human dwellings); 2) intermediate or transition region (forest under intermediate successional stage), and 3) high forest region (forest in natural conservation state). Marmosets were captured in two sites in the geographic region of phytophysiognomy 1 , an area where dwellings are arranged in the middle of the forested area, with presence of exposed sewage and garbage generated by the human population, facilities for raising domestic animals, and companion pets interacting in the environment (Fig. 1).

Tomahawk-type $(60 \times 18 \times 18 \mathrm{~cm})$ traps were placed on platforms suspended 5-6m off the ground in several sites of the study area. On catch days, the traps were armed, and the marmosets captured were transported inside the traps to the Zoonoses Research Laboratory of the CFMA, which is located near the capture sites and has adequate structure to perform the biological material collection procedures. 

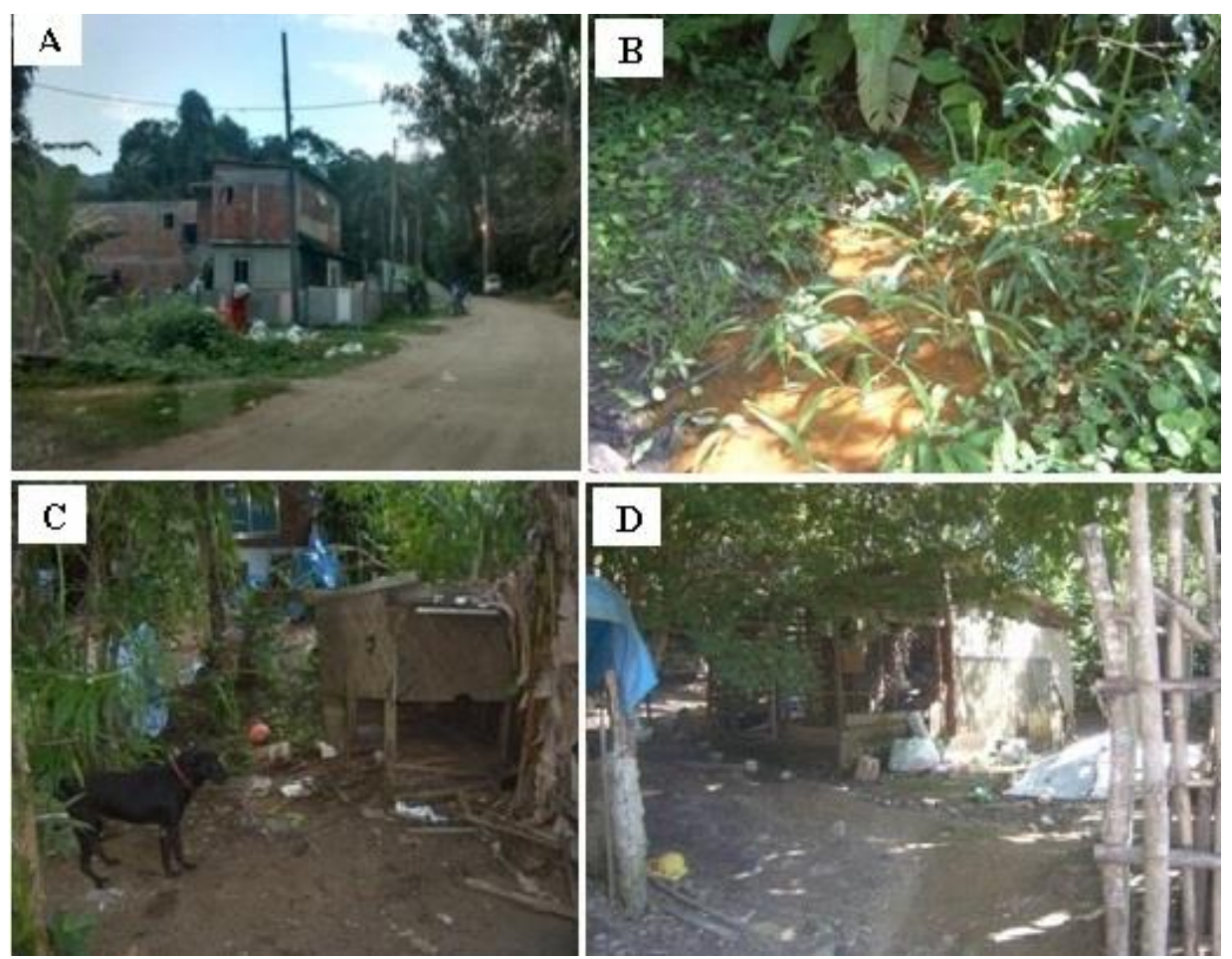

Figure 1. Regions close to the sites of where the marmosets were captured showing garbage scattered in an unprotected environment (A), exposed sewage (B), presence of companion pets (C), and facilities for raising domestic animals close to garbage accumulation (D).

The animals were anesthetized while in the traps with $10 \%$ ketamine hydrochloride (Cetamin Syntec - São Paulo, Brazil) 10mg/kg combined with $2 \%$ xylazine hydrochloride (Xilazin - Syntec - São Paulo, Brazil) $0.5 \mathrm{mg} / \mathrm{kg}$, intramuscularly (IM). The animal/trap set was weighted on a scale and the weight of the animal was obtained by the difference between the weights of the set and the empty trap. All marmosets underwent detailed clinical examination and the data collected from each animal were entered in individual records. Samples were collected from the oral cavity and rectum of the NHP using sterile swabs and taken to the CFMA laboratory in Stuart transport medium within $24 \mathrm{~h}$ for further isolation and presumptive characterization of aerobic and/or facultative anaerobic germs. All swabs were seeded on agar plates containing 5\% defibrinated sheep blood agar, Chocolate Agar supplemented with V-X factors to cover the isolation of fastidious microorganisms, and fluid thioglycollate medium with resazurin (Merck, Damstadt, Germany) to favor the less-demanding actinomycetes and anaerobes.
All isolated microorganisms were identified by conventional biochemical and automation tests (Vitek ${ }^{\circledR} 2$ bioMérieux Inc., France). Existence of multidrug resistance was investigated in all isolated microorganisms. For all the isolated enterobacteria, tests were performed for detection of extended spectrum $\beta$-lactamase (ESBL), which are enzymes that inactivate $1^{\text {st }}$ and $4^{\text {th }}$ generation penicillin and cephalosporin, and of monobactams, through the double-disc synergy and automated detection methods using a combination of drugs at pre-established concentrations, according to the manufacturer's (Vitek $^{\circledR}$ Compact, bioMérieux) instructions, following the automated methodology. Search for carbapenem-resistant enterobacteriaceae (CRE) was conducted using the imipenem, meropenem and ertapenem antibiotics, following the ANVISA (Medidas..., 2013) technical note.

For the gram-positive bacteria isolated, Staphylococcus spp. and Enterococcus spp., agar disk diffusion tests (CLSI, 2015) were conducted to investigate the existence of Sthaphylococcus aureus resistant to oxacillin (MRSA) and Enterococcus resistant to vancomycin (VRE), 
confirmed by determination of minimal inhibitory concentrations (MIC) of vancomycin by automation.

All NHP included in this study were part of a larger research project, and their use was approved by the following Ethics Committees on Animal Use under the respective licenses: CEUA FioCruz LW-63/14 and SISBIO 40968-3, and for this reason all animals were euthanized for collection and analysis of other post mortem samples.

Frequencies of each identified bacterium were calculated by the ratio between the bacterium identification frequency and the total number of samples in each cavity (oral and rectal).

\section{RESULTS}

Twenty-one samples (14 from the oral cavity and seven from the rectum) were collected from 14 marmosets (Callithrix spp.), eight males and six females, captured between May 2015 and May 2017. No changes were observed during the clinical examinations. At necropsy, macroscopic examination revealed no changes in organ color, or presence of masses and/or liquids in the abdominal and thoracic cavities of the 14 marmosets examined. The same was observed in the macroscopic examination of the brain in all animals.

In a total of 65 isolates of bacteria, 13 genera (19 species) of obtained gram negative bacteria belonging to the following families were identified, namely, one genus of the Moraxellaceae (Acinetobacter), Aeromonadaceae (Aeromonas) and Alcaligenaceae (Alcaligenes) families; eight genera of family Enterobacteriaceae (Citrobacter, Enterobacter, Escherichia, Klebsiella, Kluyvera, Leclercia, Proteus, Serratia); one genus of the Xanthomonadaceae (Stenotrophomonas) and Comamonadaceae (Comamonas) families. Of all gram-positive bacteria isolated, five genera: Bacillus (Family Bacillaceae), Enterococcus (Family Enterococcaceae), Micrococcus (Family Micrococcaceae), Staphylococcus (Family Staphylococcaceae) and Streptococcus (Family Streptococcaceae), and three species: Enterococcus faecalis, Staphylococcus aureus and Streptococcus uberis were identified (Tab. 1).
The following gram-negative bacterium species were most commonly detected in the oral cavity: K. oxytoca $(50.0 \%), K$. pneumoniae (28.6\%), Kluyvera ascorbata (21.4\%) and Stenotrophomonas maltophilia (21.4\%), and in the rectum: K. pneumoniae (85.7\%), Escherichia coli $(28.6 \%)$ and Enterobacter spp. (42.9\%), of marmosets of the CFMA (Tab. 1).

All isolates of the family Enterobacteriaceae, both from the oral cavity and the rectum, were negative for ESBL and did not produce enzymes by the two methods used: disk-diffusion and automated detection tests. In the search for CRE, these isolates presented no resistance to the imipenem, meropenem and ertapenem antibiotics.

The isolate of $S$. aureus obtained was susceptible to oxacillin (MRSA) by the disk diffusion test (CLSI, 2015) and the isolate of Enterococcus obtained was susceptible to vancomycin (VRE) by the disk diffusion test confirmed by determination of MICs of vancomycin by automation.

\section{DISCUSSION}

Studies addressing enteric bacteria infecting NHP are infrequent in the scientific literature compared with those conducted to investigate helminths, protozoa, and viruses in these primates (Nunn and Altizer, 2006). Knowledge about the intestinal bacterial flora of primates is of great importance, because it has health implications for both NHP and humans, since populations of wild animals have been considered a link in the transmission cycles of emerging pathogens that lead to occurrence of zoonotic diseases (Daszak et al., 2001; Lugano et al., 2018). These factors constitute a public health problem and a threat to biodiversity.

In this study, of the 13 genera of gram-negative bacteria isolated from the oral cavity and rectum of marmosets (Callithrix sp.) in the CFMA, eight belonged to the family Enterobacteriaceae. Some species of bacteria of this family are considered commensal for both humans and animals, such as E. coli, K. pneumoniae and Proteus mirabilis, but can lead to opportunistic infections; however, other species such as Salmonella enterica can cause serious gastroenteritis (Bublitz et al., 2015; Shigeno et al., 2018; Zaniolo et al., 2018). Results of the present study showed that $K$. pneumoniae 
was the most frequent bacterium in the rectum $(85.7 \%)$ and the second most frequent in the oral cavity $(28.6 \%)$ of the marmosets assessed. In humans, this bacterium has been described as causing infections in the urinary and respiratory tracts, nervous system, and bones, and causing formation of abscesses in organs of the abdominal cavity such as the liver (Keynan and Rubinstein, 2007).

Table 1. Frequency of the gram-positive and gram-negative, aerobic and facultative bacterial species identified from swabs of the oral cavity and rectum of free-living marmosets (Callithrix spp.) in the "Fiocruz Mata Atlântica" Campus (CFMA)

\begin{tabular}{|c|c|c|c|c|}
\hline $\begin{array}{l}\text { Aerobic and facultative bacterial } \\
\text { isolated strains }\end{array}$ & $\begin{array}{l}\text { Oral cavity } \\
\quad \mathrm{N}=14\end{array}$ & $\begin{array}{c}\text { Rectum } \\
\mathrm{N}=7\end{array}$ & $\begin{array}{c}\text { Oral } \\
\text { frequency }\end{array}$ & $\begin{array}{c}\text { Rectal } \\
\text { frequency }\end{array}$ \\
\hline Acinetobacter spp. ${ }^{\mathrm{b}}$ & 2 & & $14.3 \%$ & $0.0 \%$ \\
\hline Aeromonas caviae ${ }^{\mathrm{b}}$ & 2 & & $14.3 \%$ & $0.0 \%$ \\
\hline Aeromonas hydrophila ${ }^{\mathrm{b}}$ & 2 & & $14.3 \%$ & $0.0 \%$ \\
\hline Aeromonas spp. ${ }^{\mathrm{t}}$ & 1 & & $7.1 \%$ & $0.0 \%$ \\
\hline Alcaligenes faecalis ${ }^{\mathrm{b}}$ & 1 & & $7.1 \%$ & $0.0 \%$ \\
\hline Bacillus spp. ${ }^{\mathrm{a}}$ & 2 & & $14.3 \%$ & $0.0 \%$ \\
\hline Citrobacter diversus ${ }^{\mathrm{b}}$ & 1 & 1 & $7.1 \%$ & $14.3 \%$ \\
\hline Citrobacter freundii ${ }^{\mathrm{b}}$ & 1 & 1 & $7.1 \%$ & $14.3 \%$ \\
\hline Citrobacter sedlakii $^{\mathrm{b}}$ & 1 & & $7.1 \%$ & $0.0 \%$ \\
\hline Comamonas testosteron $^{\mathrm{b}}$ & 1 & & $7.1 \%$ & $0.0 \%$ \\
\hline Enterobacter cloacae Complex ${ }^{\text {b }}$ & 1 & & $7.1 \%$ & $0.0 \%$ \\
\hline Enterobacter aerogenes ${ }^{\mathrm{b}}$ & 1 & 1 & $7.1 \%$ & $14.3 \%$ \\
\hline Enterobacter cancerogenus ${ }^{\mathrm{b}}$ & 1 & & $7.1 \%$ & $0.0 \%$ \\
\hline Enterobacter cloacae & 1 & 2 & $7.1 \%$ & $28.6 \%$ \\
\hline Enterobacter spp. ${ }^{\mathrm{b}}$ & 1 & 3 & $7.1 \%$ & $42.9 \%$ \\
\hline Enterococcus faecalis ${ }^{\mathrm{a}}$ & 1 & & $7.1 \%$ & $0.0 \%$ \\
\hline Escherichia coli $^{\mathrm{b}}$ & 2 & 4 & $14.3 \%$ & $28.6 \%$ \\
\hline Klebsiella oxytoca ${ }^{\mathrm{b}}$ & 7 & & $50.0 \%$ & $0.0 \%$ \\
\hline Klebsiella pneumoniae ${ }^{\mathrm{b}}$ & 4 & 6 & $28.6 \%$ & $85.7 \%$ \\
\hline Kluyvera ascorbata ${ }^{\mathrm{b}}$ & 3 & & $21.4 \%$ & $0.0 \%$ \\
\hline Kluyvera cryocrescens ${ }^{\mathrm{b}}$ & 1 & & $7.1 \%$ & $0.0 \%$ \\
\hline Leclercia adecarboxylata ${ }^{\mathrm{b}}$ & 1 & & $7.1 \%$ & $0.0 \%$ \\
\hline Micrococcus spp. ${ }^{\text {b }}$ & & 1 & 0 & $14.3 \%$ \\
\hline Proteus mirabilis ${ }^{\mathrm{a}}$ & 1 & & $7.1 \%$ & $0.0 \%$ \\
\hline Serratia marcescens ${ }^{\mathrm{b}}$ & 2 & & $14.3 \%$ & $28.6 \%$ \\
\hline Staphylococcus aureus ${ }^{\mathrm{a}}$ & 1 & & $7.1 \%$ & $0.0 \%$ \\
\hline Stenotrophomonas maltophilia ${ }^{\mathrm{b}}$ & 3 & & $21.4 \%$ & $0.0 \%$ \\
\hline Streptococcus uberis ${ }^{\text {a }}$ & 1 & & $7.1 \%$ & $0.0 \%$ \\
\hline Total of isolates $(\mathrm{N}=65)$ & 46 & 19 & & \\
\hline
\end{tabular}

a-gram-positive bacteria; b- gram-negative bacteria; $\mathrm{N}$ - total of isolates

Twenhafel et al. (2008), investigating a colony of primates, verified presence of abscesses caused by $K$. pneumoniae in multiple organs of the abdominal cavity and in the brain of seven NHP of species Chlorocebus aethiops (African green monkey, an Old World NHP). Two of the animals showed clinical signs of fever and anorexia, whereas the other five were asymptomatic. Pisharath et al. (2005), at necropsy of three marmosets ( $C$. jacchus) belonging to a colony that died suddenly, observed a condition of fibrinopurulent peritonitis affecting three animals, caused byK. pneumonia, which was resistant only to ampicillin and carbenicillin. However, our results differ from those verified by the aforementioned authors, because no clinical signs or changes compatible with abdominal and brain abscesses were observed at macroscopic examination performed at necropsy in none of the marmoset assessed, even with almost all of them showing positive oral cavity and rectum cultures for $K$. pneumoniae.

Findings of the present survey corroborate those observed by Burke et al. (2009), who assessed 
swabs of the oral cavity and rectum of 307 captive NHP from three species of Old World NHP, totaling 2,297 samples, of which 195 tested positive in culture for $K$. pneumoniae, and found no clinical symptoms in the infected animals. Cruz et al. (2017) also investigated potentially pathogenic bacteria in fecal material from 29 randomly chosen captive individuals of species Macaca fascicularis (Crab-eating macaque, an Old World NHP), and observed that $79.31 \%$ of them $(\mathrm{N}=29)$ were colonized with $K$. pneumoniae but presented no clinical symptoms.

$K$. oxytoca is a bacterium species closely related to $K$. pneumonia that can cause a spectrum of similar diseases (Whitehouse et al., 2010). They are usually found in the intestines of humans and animals, water, and soil, and are currently targeted as an emerging pathogen for causing severe hospital infections and are resistant to several commonly used antibiotics (Singh et al., 2016). Nevertheless, there are few reports in the scientific literature, both on free-living and captive NHP, regarding the presence of $K$. oxytoca in these primates, especially in marmosets (Pisharath et al., 2005; Twenhafel et al., 2008; Carrier et al., 2009). This fact differs from the findings of the present study, which showed that $K$. oxytoca was the bacterium that occurred most frequently $(50 \%)$ in the oral cavity of the marmosets evaluated. Considering that the marmosets investigated in our research inhabited an anthropized region of Atlantic Forest, thus being in close contact with humans and domestic animals, our data are of extreme relevance since the high prevalence of K.oxytoca in marmosets indicates that a probable transfer of bacterial agents is occurring between the human and NHP populations. Zaniolo et al. (2018), in a study conducted with free-living Sapajus nigritus (Black Capuchin) belonging to an urban park in the northern region of Parana state also suggested that the 11 species of enterobacteria isolated in these NHP belong mainly to the human microbiota, and that they would be crossing the interspecific barrier and beginning to colonize these NHP.

In the marmosets evaluated in this study, E. coli was seldom detected in the oral cavity, and was the second most frequent species isolated from swabs of the rectum (28.6\%). Similar to our findings, a study evaluating free-living and captive Leontopithecus chrysopygus (Black Lion
Tamarin) showed low frequency of E.coli in the oral cavity and high frequency (the most frequent bacterium) in the rectum (Carvalho et al., 2014).

Bublitz et al. (2015), aiming to investigate the presence of enterobacteria in free-living NHP, evaluated samples of feces of 24 lemurs from two different areas at the perimeter of a park on the island of Madagascar: 11 animals were sampled in an area where the forest was fully preserved and 13 animals were captured in an area that had undergone strong anthropic pressure, with presence of dwellings, practice of agriculture, and raising of domestic animals. The researchers also collected fecal samples from humans and domestic animals and found that $E$. coli showed a prevalence rate of $60 \%$ in lemurs from the anthropized region. Bublitz et al. (2015) found there was no presence of enterobacteria in the fecal samples collected from the lemurs in the area where the forest was fully preserved. These findings reinforce the results observed in our study and strengthen the understanding of a probable bacterial transmission between NHP, humans, and domestic animals. Therefore, further studies are needed to better understand the possible transmission routes between these different groups in an attempt to identify whether it is through direct contact between animals and humans that these pathogens are transferred, or whether anthropized environments end up exposing wild animals to the risk of these bacterial agents.

The proximity of human population to the forested environment and consequently to wild animals, especially NHP, also induce the occurrence of bite accidents. The marmoset's approach dwellings searching food and may directly bite the humans (Sobreira et al., 2019). The bacterial microbiota of the oral cavity of Callithrix sp. is similar to that of humans (Haddad Junior, et al., 2013; Takehara et al., 2019), however, an NHP bite can cause severe traumatic and infectious injury if not properly treated with antibiotics. In this kind of incident, there is also the risk of transmission of viral agents such as rabies virus and herpesvirus (Haddad Junior et al., 2013; Sobreira et al., 2019). In the present study, the bacteria isolated from the oral cavity of marmosets, are regarded as potentially pathogenic to humans, may cause severe infection, including abscess formation at the bite site (Burke et al., 
2009; Carvalho et al., 2014; Sales, 2015; Singh et al., 2016; Cruz et al., 2017; Shigeno et al., 2018).

Among the gram-positive microorganisms isolated on swabs from the oral cavity of the callitrichids assessed, the isolate of $S$. aureus obtained was susceptible to oxacillin (MRSA) by the disk diffusion test (CLSI, 2015) and the isolate of Enterococcus obtained was susceptible to vancomycin (VRE) by the disk diffusion test confirmed by determination of MICs of vancomycin by automation. These findings differ from the observed by Sales (2015), who investigated Callithrix sp. and Leontopithecus rosalia (Golden Lion Tamarin) and detected coagulase-negative staphylococci with high frequency resistance to oxacillin, fusidic acid and penicillin. Sobreira et al. (2019) isolated S. aureus in $100 \%$ of the oral cavity samples collected from free-living Sapajus libidinosus (Bearded Capuchins) in the state of Goias that were highly resistant to antibiotics, including tetracycline, erythromycin and clindamycin. Grassotti et al. (2018) collected sample from swabs of the rectum of 24 S. apella (Tufted Capuchins), 19 free-living and five captive animals, totaling 296 isolates of Enterococcus spp., and found that $67.9 \%$ of them were not susceptible to at least one of the antibiotics tested. Although Grassoti et al. (2018) and Sobreira et al. (2019) have tested antibiotics from groups different from those tested in the present study, their findings differ from our results; however, the present study obtained one isolate of S. aureus and one isolate Enterococcus susceptible to the antibiotics tested, thus requiring a larger number of isolates for a better evaluation of resistance to antibiotics.

In the present study, all isolates of the family Enterobacteriaceae were negative for ESBL and showed no resistance to CRE, differing from studies conducted in the past three decades, which show that members of this family have multidrug resistant characteristics due to production of ESBL and resistance to CRE (Davin-regli and Pagès, 2015).

Köck et al. (2018) reported that wildlife acquires bacteria resistant to antibiotics through contact with sewage, manure, or waste disposal sites. Regardless of the source of soil and water contamination, wild species that feed in environments exposed to these contaminating sources may be infected by ARB and disseminate them even more (Arnold et al., 2016; Vittecoq et al., 2016). In the present study, although the evaluated marmosets lived in an anthropized environment close to human dwellings and in contact with potential contaminating sources such as sewage and residues from domestic animals that are released in the environment when not appropriately treated, antimicrobial resistance characteristics were not observed by the tests performed in the bacterial isolates obtained. However, we suggest that this is a favorable scenario for the occurrence of transmission of bacterial agents between NHP and human beings, and vice versa.

\section{CONCLUSIONS}

It is worth emphasizing that all bacteria isolated in the present study show zoonotic potential, and can cause harm to the health of humans, domestic and wild animals, highlighting the relevance of this research for the field of public health and biodiversity. In view of these results, future studies addressing the bacterial microbiota of nonhuman primates (NHP) are fundamental for a better understanding of the dynamics of these bacteria, seeking a more comprehensive knowledge of their behavior in the interaction between humans and NHP, in addition to correlating whether anthropized environments favor the transmission of these pathogens between these two populations.

\section{ACKNOWLEDGMENTS}

This study was financed in part by the Coordenação de Aperfeiçoamento de Pessoal de Nível Superior - Brasil (CAPES) - Finance Code 001 and Instituto Oswaldo Cruz, Brazil.

\section{REFERENCES}

ARNOLD, K.E.; WILLIAMS, N.J.; BENNETT, M. Disperse abroad in the land':the role of wildlife in the dissemination of antimicrobial resistance. Biol. Lett., v.12, p.1-8, 2016.

BEGOTTI, R.A.; LANDESMANN, L.F. Predação de ninhos por um grupo híbrido de sagüis (Callithrix jacchus/penicillata) introduzidos em área urbana: implicações para a estrutura da comunidade. Neotrop. Primates, v.15, p.28-29, 2008. 
BUBLITZ, D.C.; WRIGHT, P.C.; RASAMBAINARIVO, F.T. et al. Pathogenic Enterobacteria in lemurs associated with anthropogenic disturbance. Am. J. Primatol., v.77, p.330-337, 2015.

BURKE, R.L.; WHITEHOUSE, C.A.; TAYLOR, J.K.; SELBY, E.B. Epidemiology of invasive Klebsiella pneumonia with hypermucoviscosity phenotype in a research colony of nonhuman primates. Am. Assoc. Lab. Anim. Sci., v.59, p.589597, 2009.

CARRIER, C.A.; ELLIOT, T.B.; LEDNEY, G.D. Resident bacteria in a mixed population of rhesus macaque (Macaca mulatta) monkeys: a prevalence study. J. Med. Primatol., v.38, p.397403, 2009.

CARROL，D.; WANG，J.; FANNING， S.; McMAHON, B.J. Antimicrobial resistance in wildlife: implications for public health. Zoonoses Public Health, v.62, p.1-9; 2014.

CARVALHO, M.V.; VANSTREELS, R.E.T.; PAULA, C.D. et al. Nasal, oral and rectal microbiota of black lion tamarins (Leontopithecus chrysopygus). Braz. J. Microbiol., v.45, p.15311539, 2014.

CLSI. Methods for dilution antimicrobial susceptibility tests for bacteria that grow aerobically; Approved standards-Tenth Edition. CLSI document M07-A10. 10. Wayne: Clinical Laboratory Standards Institute; 2015.

CRUZ, P.B.; SANTOS, F.N.; ESTEVES, W.T. et al. Pesquisa de microbiota normal e de bactérias potencialmente patogênicas em material fecal de primatas não humanos da espécie Macaca fascicularis de cativeiro. Rev. Soc. Bras. Ciênc. Anim. Lab., v.4, p.147-148, 2017.

DASZAK, P.; CUNNINGHAM, A.A.; HYATT, A.D. Anthropogenic environmental change and the emergence of infectious diseases in wildlife. Acta Trop., v.78, p.103-116, 2001.

DAVIN-REGLI, A.; PAGÈS, J.M. Enterobacter aerogenes and Enterobacter cloacae: versatile bacterial pathogens confronting antibiotic treatment. Front. Microbiol., v.6, p.1-10, 2015.

GRASSIOTTI, T.T.; ZVOBODA, D.A.; COSTA, L.F.X. et al. Antimicrobial resistance profiles in Enterococcus spp. isolates from fecal samples of wild and captive black capuchin monkeys
(Sapajus nigritus) in South Brazil. Front. Microbiol, v.9, p.1-10, 2018.

HADDAD JUNIOR, V.; CAMPOS NETO, M.F.; MENDES, A.L. Mordeduras de animais (selvagens e domésticos) e humanas. J. Trop. Pathol., v.42, p.13-19, 2013.

KEYNAN, Y.; RUBINSTEIN, E. The changing face of Klebsiella pneumonia infections in the community. Int. J. Antimicrob. Agents, v.30, p.385-389, 2007.

KIM, J.; COBLE, D.J.; SALYARDS, G.W. et al. Antimicrobial use for and resistance of zoonotic bacteria recovered from nonhuman primates. Comp. Med., v.67, p.79-86, 2017.

KÖCK, R.; DANIELS-HAARDT, I.; MELLMANN, A. et al. Carbapenem-resistant Enterobacteriaceae in wildlife, food-producing and companion animals - a systematic review. Clin. Microbiol. Infect., v.24, p.1241-1250, 2018.

LUGANO, S.D.; NYERERE, K.A.; KARIUKI, W.K. et al. Gastrointestinal microbial flora in wild and captive olive baboons (Papio anubis). Am. J. Infect. Dis. Microbiol., v.6, p.30-37, 2018.

MEDIDAS de prevenção e controle de infecções por enterobactérias multiresistente. Brasília: Agência Nacional de Vigilância Sanitária, 2013. (Nota Técnica, n.01). 22p.

NUNN, C.; ALTIZER, S.M. (Eds.). Infectious diseases in primates: behavior, ecology and evolution. Oxford: Oxford University Press, 2006. 400p.

PISHARATH, H.R.; COOPER, T.K.; BRICE, A.K. et al. Septicemia and peritonitis in a colony of common marmosets (Callithrix jacchus) secondary to Klebsiella pneumoniae infection. Am. Assoc. Lab. Anim. Sci., v.44, p.35-37, 2005.

REFLORESTAMENTO do parque estadual da Pedra Branca. Rio de Janeiro: IBIO, 2014. Available in: <http://ibio.org.br/\#section-home>. Accessed in: 8 Jan. 2018.

ROCHA, M.F.; PASSAMANI, M. Uso do espaço por um grupo de saguis-da-cara-branca (Callithrix geoffroyi) no sudeste do Brasil. Bol. Museu Biol. Mello Leitão, v.26, p.47-58, 2009.

RUIZ-MIRANDA， C.R.; JÚNIOR， M.M.M.; PAULA, V.R. et al. Os problemas dos saguis introduzidos no Rio de Janeiro - vítimas e vilões. Ciênc. Hoje, v.48, p.44-49, 2011. 
SALES, I.S. Avaliação da sanidade e da microbiota de híbridos de saguis (Callitrhix sp.) e mico-leão-dourado (Leontopithecus rosalia) de vida livre no estado do Rio de Janeiro. 2015. 108f. Tese (Doutorado em Ciência Animal) Universidade Estadual do Norte Fluminense Darcy Ribeiro, Campos dos Goytacazes, RJ.

SHIGENO, Y.; TOYAMA, M.; NAKAMURA, $\mathrm{M}$. et al. Comparison of gut microbiota composition between laboratory-bred marmosets (Callithrix jacchus) with chronic diarrhea and healthy animals using terminal restriction fragment length polymorphism analysis. Microbiol. Immunol., v.62, p.702-710, 2018.

SINGH, C.L.; CARIAPPA, M.P.; KAUR, M. Klebsiella oxytoca: an emerging pathogen? Med. J. Armed Forces India, v.72, p.s59-s61, 2016.

SOBREIRA, E.A.; BRAGA, C.A.S.B.; RAHAL, S.C. et al. Oral microbiota and their antibiotic susceptibility in free-living monkeys in Goiás State, Brazil: repercussions for injuries in humans. J. Braz. Soc. Trop.l Med., v.52, p.1-4, 2019.
TAKEHARA, S.; ZEREDO, J.L.; KUME, Y. et al. Characterization of oral microbiota in marmosets: Feasibility of using the marmoset as a human oral disease model. Plos One, v.14, p.1-11, 2019.

TWENHAFEL, N.A.; WHITEHOUSE, C.A.; STEVENS, E.L. et al. Multisystemic abscesses in african green monkeys (Chlorocebus aethiops) with invasive Klebsiella pneumoniaeidentification of the hypermucoviscosity phenotype. Vet. Pathol., v.45, p.226-231, 2008.

VITTECOQ, M.; GODREUIL, S.; PRUGNOLLE, F. et al. Antimicrobial resistance in wildlife. J. Appl. Ecol., v.53, p.519-529, 2016.

WHITEHOUSE, C.A.; KEIRSTEAD, N.; TAYLOR, J. Prevalence of hypermucoid Klebsiella pneumoniae among wildcaught and captive vervet monkeys (Chlorocebus aethiops sabaeus) on the Island of St. Kitts. J.Wildl. Dis., v.46, p.971-976, 2010.

ZANIOLO, M.M.; OLIVEIRA, A.F.; TRAMONTIN, R.S. et al. Identification of enterobacteria in free-living nonhuman primates in an urban park in the northern region of the state of Paraná, Brazil. Semin. Ciênc. Agrár., v.39, p.1115-1124, 2018. 